\title{
Regulatory immune cells and functions in autoimmunity and transplantation immunology
}

review article

Gabor Papp MD, $\mathrm{PhD}^{1}$, Peter Boros $\mathrm{MD}, \mathrm{PhD}^{2}$, Britt Nakken $\mathrm{PhD}^{3}$, Peter Szodoray MD, $\mathrm{PhD}^{3}$ and Margit Zeher MD, PhD, $\mathrm{DSc}^{1}$

${ }^{1}$ Division of Clinical Immunology, Faculty of Medicine, University of Debrecen, Móricz Zs. str. 22. Debrecen, Hungary, H-4032

${ }^{2}$ Recanati/Miller Transplant Institute, Department of Surgery, Icahn School of Medicine at Mount Sinai, One Gustave L. Levy Place New York, NY 10129, USA.

${ }^{3}$ Centre for Immune Regulation and Department of Immunology, University of Oslo, Oslo University Hospital, Rikshospitalet, Sognsvannsveien 20. Oslo, Norway, N-0027

Correspondence: Margit Zeher MD, PhD, DSc

Division of Clinical Immunology, Faculty of Medicine, University of Debrecen Address: Moricz Zs. str. 22., H-4032 Debrecen, Hungary

Tel/Fax: +36-52-255-218; E-mail: zeher@iiibel.dote.hu 


\begin{abstract}
In physiological circumstances, various tolerogenic mechanisms support the protection of self-structures during immune responses. However, quantitative and/or qualitative changes in regulatory immune cells and mediators can evoke auto-reactive immune responses, and upon susceptible genetic background, along with the presence of other concomitant etiological factors, autoimmune disease may develop. In transplant immunology, tolerogenic mechanisms are also critical, since the balance between of alloantigen-reactive effector cells and the regulatory immune cells will ultimately determine whether a graft is accepted or rejected. Better understanding of the immunological tolerance and the potential modulations of immune regulatory processes are crucial for developing effective therapies in autoimmune diseases as well as in organ transplantation.

In this review, we focus on the novel insights regarding the impaired immune regulation and other relevant factors contributing to the development of auto-reactive and graft-reactive immune responses in autoimmune diseases and transplant rejection, respectively. We also address some promising approaches for modification of immune-regulatory processes and tolerogenic mechanisms in autoimmunity and solid organ transplantation, which may be beneficial in future therapeutic strategies.
\end{abstract}

Keywords: autoimmunity, regulatory cells, systemic autoimmune diseases, tolerance induction, transplant rejection 


\section{Introduction}

The key role of the immune system is to effectively eliminate pathogens, at the same time leave self-structures unharmed. The protection of self-antigens encompasses several types of controlling mechanisms. In healthy immune system, various central and peripheral tolerance mechanisms exist, such as activation-induced cell death, anergy, clonal ignorance and network of peripheral regulatory cells, which play a protective role to prevent the activation of self-reactive lymphocytes. Immune suppression can be achieved by either cell-cell contact, or via soluble mediators, e.g. anti-inflammatory cytokines. More and more cell types have been shown to have regulatory capacity; besides regulatory B-cells, or regulatory dendritic cells, a key member of the family of immunoregulatory cells are regulatory $\mathrm{T}$ cells (Tregs). In autoimmune conditions, the alteration or even breakdown of the aforementioned immune tolerance mechanisms potentially leads to the survival and activation of autoreactive lymphocytes upon encountering the appropriate autoantigen, which may results in consequential tissue and organ damages [1]. In the pathogenesis of autoimmune diseases, various cellular and humoral immune processes have been described both in the innate and adaptive immune systems, including disturbed apoptotic processes, altered cytokine milieu and disproportional $\mathrm{T}$ and $\mathrm{B}$ cell activation, which result in exaggerated immune responses [2].

Undesirable immune activation is a crucial factor in transplant immunology, as well. Transplantation of solid organs between genetically distinct individuals, in the absence of immunosuppression, will lead to graft-reactive T cell activation upon encountering transplantderived antigens, which results in transplant rejection [3].

Better understanding of the alterations in immunological tolerance and the potential modulations of the immune regulation are crucial for the effective therapy of autoimmune 
diseases. Additionally, despite the potent immunosuppressive medications, induction of tolerance remains a major goal in transplantation, as well.

\section{Regulatory functions of innate and adaptive immune cells}

By recognizing and discriminating self and non-self structures, innate immune system is regarded as the first critical line against infections. Innate immune cells, such as macrophages or dendritic cells (DCs), present pattern recognition receptors (PRRs), such as Toll-like receptors (TLRs), retinoic acid-inducible gene I (RIG-I)-like receptors (RLRs) and nucleotide-binding domain and leucine-rich repeat containing molecules (NLRs), which recognize molecules that are broadly shared by pathogens but distinguishable from host molecules, collectively referred to as pathogen-associated molecular patterns (PAMPs) [4]. This recognition triggers a series of signaling cascades that culminate in the activation of transcriptional factors nuclear factor- $\kappa \mathrm{B}(\mathrm{NF}-\kappa \mathrm{B})$, interferon regulatory factor (IRF) and activator protein-1 (AP-1), which induce a number of downstream genes encoding a broad range of inflammatory cytokines, chemokines, antimicrobial peptides, complement factors and interferons in the activated cells [5].

Dendritic cells play important roles in the initiation and modulation of adaptive immune responses. DCs, which constitute highly heterogeneous cell populations with distinct developmental origins, are generally divided into three main types in human blood. The $\mathrm{CD} 23^{+} \mathrm{BDCA}^{-2}(\mathrm{CD} 303)^{+}$plasmacytoid DCs (pDCs) react to viral infections by secreting type I interferons (IFN), while the two types of $\mathrm{CD}_{11 \mathrm{c}^{+}}$myeloid $\mathrm{DCs}(\mathrm{mDCs})$ consist of CD1c+ and CD141+ mDCs exert phagocytic activity and are important in antigen presentation to antigen-specific T-cells [6,7]. Activated DCs play essential roles in 
determining the activation and differentiation of $\mathrm{T}$-cell subsets, by expressing a numerous inflammatory cytokines, chemokines, co-stimulatory molecules and MHC molecules allowing presentation of antigens to T cells $[8,9]$. The maturation state of DCs is also linked to specific function. Immature DCs are highly immunogenic and promote T cell polarization toward proinflammatory T-helper (Th)1, Th2 and Th17 subtypes, on the contrary, immature DCs are rather tolerogenic by expressing low levels of costimulatory molecules and producing antiinflammatory mediators [e.g. interleukin (IL)-10, transforming growth factor (TGF)-beta] [10]. DCs are seems to be also important for inducing immune tolerance toward harmless components. It is supposed that in the absence of activation, DCs promote tolerance, through either induction of Treg cells or T cell unresponsiveness [11].

Recent studies shed light on the importance of the myeloid-derived suppressor cells (MDSCs) in tolerogenic mechanisms. MDSCs are a heterogeneous group of immature myeloid cells with immunoregulatory function, characterized by an "immature" phenotype, on the basis of expression of the common myeloid marker CD11b, the expression of CD33 and the absence/low levels of HLA-DR. In steady state conditions, MDSC precursors reside primarily in the bone marrow; however, in certain pathological conditions such as infections, transplantation or malignant tumor, MDSC populations expand and can be detected in the blood and the inflammatory sites. After migrating from the bone marrow, MDSC suppress T cell functions via a number of different mechanisms involving both soluble mediators and cell-cell contact and thereby, generally prevent immune responses [12].

At the level of adaptive immune system, the network of Treg cells is primarily responsible for the maintenance of self-tolerance. Among others, the two major representatives of this system are denoted as induced Treg cells (iTreg) and $\mathrm{CD}^{+} \mathrm{CD} 25^{\text {bright }}{ }^{\mathrm{FoxP}} 3^{+}$natural Treg cells $[13,14]$. The iTreg $\mathrm{CD}^{+} \mathrm{T}$ cells gain their suppressor function following activation. In the regulation of peripheral $\mathrm{T}$ cell immune responses, several types of iTreg cells participate, 
where the most widely investigated subsets are the IL-10-producing T regulatory type $1(\operatorname{Tr} 1)$ cells and TGF-beta-producing Th3 cells $[15,16]$. Accumulating evidence suggests that the induction by commensal microbes in the gut is the major source of peripheral Treg cells, which raises the relevance of probiotic and prebiotic approaches as potential treatments for autoimmune diseases [17].

Another, recently discovered $\mathrm{CD}^{+} \mathrm{T}$ cell type, the follicular $\mathrm{T}$ helper $\left(\mathrm{T}_{\mathrm{FH}}\right)$ cells plays an important role in immune responses by mediating antigen specific naive or memory $\mathrm{B}$ cell activation in the B-cell follicles of secondary lymphoid organs. The interplay of $\mathrm{T}_{\mathrm{FH}}$ and activated B-cells is essential for the generation of extrafollicular short-lived plasma cells producing low-affinity antibodies and for germinal centre (GC) responses as well. Within GC, $\mathrm{T}_{\mathrm{FH}}$ cells promote the development of high-affinity memory B-cells and long-lived plasma cells by providing survival signals to centrocytes, which have undergone somatic hypermutation. Based on the critical role of $\mathrm{T}_{\mathrm{FH}}$ cells in $\mathrm{B}$-cell activation and antibody production, their failure to maintain self-tolerance potentially leads to the development of autoreactive immune processes [18]. Factors responsible for limiting the availability and function of $\mathrm{T}_{\mathrm{FH}}$ cells are still not elucidated yet. However, a recently identified new subset of Treg cells, the follicular regulatory $\mathrm{T}$ cells $\left(\mathrm{T}_{\mathrm{FR}}\right)$ seem to have an important role in regulating $\mathrm{T}_{\mathrm{FH}}$ cells and preventing the development of autoreactive $\mathrm{B}$ cells [19]. Regarding $\mathrm{B}$ cell contribution to the function of immune system, besides the well established proinflammatory, such as antigen-presenting and antibody-producing role of B cells, certain B cell subsets, so-called regulatory $\mathrm{B}$ (Breg) cells have a negative regulatory effect by producing regulatory cytokines such as interleukin (IL)-10, and interacting directly with activated $\mathrm{T}$ cells via cell-to-cell contact [20]. Based on the expression of various surface molecules, several populations of Bregs have been reported including B10 cells, $\mathrm{CD} 1 \mathrm{~d}^{\text {hi }} \mathrm{CD}^{+} \mathrm{CD} 19^{+} \mathrm{B}$ cells, $\mathrm{CD} 19^{+} \mathrm{CD} 24^{+} \mathrm{CD} 38^{+} \mathrm{B}$ cells or $\mathrm{CD} 19^{+} \mathrm{CD} 24^{+} \mathrm{CD} 27^{+} \mathrm{B}$ cells etc.; 
however, interleukin (IL)-10-production was recognized as one of the most important characters of functional Bregs. By producing IL-10, Bregs suppress the differentiation and proliferation of IL-17-producing Th17 cells, inhibits the secretion of IFN- $\gamma$, and reduces the accumulation of natural killer (NK) cells, as well [21].

\section{Imbalance of effector/regulatory functions and cytokine profiles in autoimmunity and systemic autoimmune diseases}

When quantitative and/or qualitative changes occur in regulatory immune cells, proinflammatory immune responses can be evoked, and upon susceptible genetic background, along with the presence of other concomitant etiological factors, autoimmune processes can occur, and eventually various autoimmune diseases may develop. In systemic autoimmune diseases, a selective decrease in the number and/or reduced suppressor function of Tregs have been described [22-27]. In a forerunner medical condition for systemic autoimmune diseases, denoted as undifferentiated connective tissue disease (UCTD), the percentage and absolute number of $\mathrm{CD} 4^{+} \mathrm{CD} 25^{\text {bright }} \mathrm{FoxP}^{+}$Treg cells were reduced, while the number of inducible Tregs $\left(\mathrm{CD} 4^{+} \mathrm{IL}-10^{+}\right)$was increased in UCTD patients compared with healthy subjects [28]. This progressive divergent shift in natural and induced Tregs clearly predicted the transition from the UCTD, introductory phase to a well-established systemic autoimmune disease [28]. These findings underline the possibility that years before the development of a full-blown autoimmune disease, derailed immune-regulatory processes take place and drive the pathology forward. In line with this notion, in the active phase of systemic autoimmune diseases, the ratios of natural Tregs was found to be decreased compared to patients with 
inactive disease [22,24,29]. In autoimmune conditions, the other major regulatory $\mathrm{T}$ cell subset, the IL-10 producing Tr1 has been found to differ quantitatively and qualitatively from that of healthy individuals and therefore have an important role in the development of various autoimmune diseases [30]. The IL-10 cytokine besides other functions can suppress the IFN- $\gamma$ production of Th1 cells as well as having other important regulatory roles in differentiation of various lymphocyte subsets [31,32]. A significant increase in the number of IL-10 producing Tr1 cells has been described in UCTD and further increase was depicted in patients who progressed into definitive systemic autoimmune diseases. We assume that this phenomenon represents a compensatory mechanism in order to counter-regulate the effects of the observed IFN- $\gamma$ overproduction [28].

In certain, pro-inflammatory conditions, T-cells have the ability to differentiate into Th17 cells, and this process is independent of Th1 or Th2 cell development [33]. Th17 polarization requires the presence of IL-1 $\beta$, IL-6, IL-21, and IL-23, which cytokines induce the activation of the transcription factor signal transducer and activator of transcription 3 (STAT3). Generally, Th17 cells have a major function in combat against pathogens, they recruit neutrophils and macrophages to the site of inflammation, they are crucial in the initiation of inflammation, mostly against extracellular pathogens [34]. However, the persistent secretion of IL-17 promotes chronic inflammation and can contribute to the pathogenesis of inflammatory and autoimmune diseases. Increased proportion of Th17 cells and level of secreted IL-17 have been associated with numerous inflammatory conditions, and autoimmune diseases, such as SLE [35], Sjögren's syndrome [36] and systemic sclerosis [37]. As we pinpointed previously, the imbalance of pro- and anti-inflammatory mechanisms, indicated by amongst others, Th17 and Treg numbers, or biased cellular functions may initiate and perpetuate autoimmune diseases. Circulating and local skewed cytokine milieu alters the suppressive function of Treg cells. In affected organs of patients with autoimmune diseases 
increased IL-6 and transforming growth factor (TGF)- $\beta$ expression has been described which favor the development of Th17 cells. Moreover, increased concentrations of tumor necrosis factor (TNF)- $\alpha$, which is characteristic to numerous autoimmune diseases, down-modulates the function of Tregs, further contributing to the disequilibrium between the pro- and antiinflammatory processes [38].

\subsection{Primary Sjögren's syndrome (SS)}

Primary Sjögren's syndrome (pSS) is a common, chronic, slowly progressive systemic autoimmune disease that predominantly affects the middle-aged women. Histologically, pSS is characterized by mononuclear infiltration and destruction of the exocrine glands, clinically resulting in dry mouth, keratoconjunctivitis sicca and the presence of various exocrinopathic symptoms [39]. In the pathogenesis, different subsets of immune-competent cells, e.g. lymphocyte subsets, dendritic cells and monocytes play a pivotal role. Similarly to other systemic autoimmune diseases, increased cell activation, disproportional programmed cell death, in parallel with faulty autoantigen scavenging are important in the pathogenesis, which processes are partly driven by a skewed cytokine milieu [40,41]. A group of circulating proinflammatory cytokines, chemokines and growth factors has been implicated in the pathogenesis of pSS, contributing to the initiation and perpetuation of the cellular and humoral autoimmune processes. In patients with pSS, the following circulating mediators were reported to be increased compared to healthy subjects: IL-1 $\beta$, IL-2, IL-6, IL-15, IFN- $\gamma$ and chemokine (C-C motif) ligand 4 (CCL4 or MIP-1 $\beta$ ) [42]. The skewed T-cell subsets and circulating cytokine imbalance seem to play important roles in an orchestrated proinflammatory cascade in pSS. Diminished suppressor activity of $\mathrm{CD} 4^{+} \mathrm{CD} 25^{\text {bright }}$ Treg cells, along with elevated circulating TNF-alpha and IL-6, and reduced IL-10 has also been demonstrated in pSS giving raise to the development of autoimmune processes [25]. 
Moreover, circulating cytokines have the ability to distinguish/drive pSS patients with ectopic salivary gland germinal centers, a possible forerunner of lymphoma development in the disease $[43,44]$. Our study on pSS patients with ectopic germinal center formation identified a group of biomarkers which could distinguish from healthy individuals, namely IL-4, IL-10, granulocyte-macrophage colony-stimulating factor (GM-CSF), IFN- $\alpha$, CCL3 (MIP-1 $\alpha$ ), CCL11 (Eotaxin) and B-cell activating factor (BAFF/BLyS), while germinal center positive and negative pSS patients differed in CCL2 (MCP-1) expression. Interestingly, based on multivariate statistical analyses, the biomarker with the strongest discriminatory power amongst SS patients with, or without ectopic salivary gland germinal centers were CCL11 (Eotaxin), IFN- $\gamma$, as well as BAFF/BLyS [42]. Taken these findings together, a group of mediators (e.g. cytokines and chemokines) has the ability to create a pro-inflammatory milieu in pSS patients, presumably contributing to a derailed Th17/Treg balance, as well.

Humoral autoimmune responses, $\mathrm{B}$ cell activation and autoantibody production are also important immune abnormalities in pSS. Recent investigations shed light on altered $\mathrm{T}_{\mathrm{FH}}$ profiles in pSS, suggesting the important role of $\mathrm{T}_{\mathrm{FH}}$ cells and IL-21 cytokine secretion in autoreactive B cell activation and autoantibody production [45]. Additionally, in labial salivary gland biopsies of pSS patients, $\mathrm{T}_{\mathrm{FH}}$ cell markers, such as CD84, programmed cell death protein 1 (PD-1) and Bcl-6 were detected in the lymphocytic infiltrations, especially, in more organized lymphoid structures [46]. A recent study suggest that enhanced IL-21 receptor expression of $\mathrm{CD}_{1} 9^{+} \mathrm{CD}^{+} \mathrm{B}$ cells and enhanced production of IL-21 by $\mathrm{T}_{\mathrm{FH}}$ and iNKT cells may play an important role in the pathogenesis of pSS by regulating $\mathrm{C}_{1} 9^{+} \mathrm{CD}^{+} \mathrm{B}$ cell functions and increasing granzyme B production, presumably leading to a counterregulatory effect in the disease [47].

\subsection{Systemic Lupus Erythematosus (SLE)}


SLE is one of the most well-known systemic autoimmune diseases, mostly affecting younger females, characterized by various organ involvements, encompassing mild to moderate forms, and also severe, progressive variants [48]. A number of cytokines have been implicated in the pathogenesis of the disease, including BAFF/BLyS, TNF- $\alpha$, IFN- $\alpha$, IFN- $\gamma$, IL-12, IL-23, IL18, IL-6, IL-10 and IL-17 [49,50].

The backbone of inflammation in SLE is denoted as interferon-signature. The assessment of the key role of this in lupus, led to the discovery of interferon regulatory factor-5 (IRF5), which has been shown to be linked to the increased production of IFN- $\alpha$, and STAT4. This unique gene expression profile seemed to be responsible for increased sensitivity to IFN- $\alpha$ [51-53]. The disease course of SLE is characterized relapses and remissions in many cases. Patients with disease flare had significant alterations in a wide variety of soluble mediators at baseline with significantly higher levels of pro-inflammatory mediators, -similarly to other systemic autoimmune diseases- including Th1, Th2, and Th17-type cytokines, several weeks before clinical flare compared to clinically stable patients [54]. On the other hand, regulatory cytokines, including IL-10 and TGF- $\beta$ were higher in non-flare SLE patients [54]. Furthermore, peripheral Treg cell number and function have been shown impaired in SLE [55,56], along with increased peripheral Th17 cells ratios and serum IL-17 concentrations, especially in patients with active disease $[57,58]$. The Th17 and Treg ratio indicates that SLE is associated with a reduction in the levels and function of immunosuppressive Treg cells together with an increase in the pro-inflammatory Th17 cells [59].

It is well established in lupus that the imbalance of different subsets of B cells is also crucial for the initiation and perpetuation of the disease. Elevated percentages of circulating $\mathrm{CD}^{+} \mathrm{CXCR}^{+} \mathrm{ICOS}^{+} \mathrm{PD}-1^{+} \mathrm{T}_{\mathrm{FH}}$ cells were reported in SLE patients. Notably, these cell proportions showed associations with autoantibody titres and the altered ratios of $\mathrm{B}$ cell subpopulations [60]. 


\subsection{Systemic sclerosis}

Systemic sclerosis (SSc) is a systemic autoimmune disease with excessive extracellular matrix deposition and damage of small blood vessels. The autoinflammatory processes lead to the damage of the skin, as well as various visceral organs, such as the heart, lungs, or kidneys [61]. The three main processes can be distinguished in disease development: endothelial damage and dysfunction, pathological immune activation and fibrosis of the affected tissues. The immuno-regulatory abnormalities are in the focus of intense research in SSc. Disorders of the immune system lead to chronic inflammatory processes, abnormal $\mathrm{T}$ cell activation, $\mathrm{B}$ cell abnormalities, pathogenic autoantibody production and the release of pro-inflammatory cytokines, as well as pro-fibrotic mediator.

Altered balance of Th1 and Th2 cytokines may contribute to the development of fibrosis. In Th2 predominance, plasma level of IL- 4 increases, which induces the TGF- $\beta$ production leading to fibroblast proliferation and accelerated collagen synthesis [62].

The Th17 cells are major contributors to autoimmune processes, and former studies have demonstrated that SSc patients have increased peripheral Th17 cell percentages along with elevated circulating IL-17 levels. Th17 cells also induce TGF- $\beta$ synthesis and fibroblast proliferation, which underline the potential involvement of Th17 cells in the pathogenesis of SSc $[63,64]$.

Additionally, Tregs with impaired function have been shown to play a role in the initiation and perpetuation of the disease. We have previously described increased Th17/Treg ratio and the altered regulatory function of Treg cells which play a pivotal role in the development and progression of SSc $[37,65,66]$. Taken together, SSc patients are characterized by higher percentages of activated $\mathrm{T}$ cells, and a shift has been shown between the effector and 
regulatory T cells. Increased Th17 cell percentages, together with decreased levels of Th1, and altered regulatory $\mathrm{T}$ cell subsets are also characteristic to SSc [37].

\subsection{Mixed Connective Tissue Disease}

Clinically, mixed connective tissue disease (MCTD) is diagnosed based on a group of symptoms, such as arthritis, Raynaud's phenomenon, myositis, esophageal dysmotility, and acrosclerosis along with the presence of autoantibodies reactive with U1 small nuclear RNP (U1RNP) autoantigens [67]. Serum concentrations of both Th1 and Th2 cytokines were significantly elevated in MCTD. Furthermore, the percentage of IL-10-producing CD4 ${ }^{+}$and $\mathrm{CD}^{+} \mathrm{T}$ cells was higher in patients than in controls, and $\mathrm{CD}^{+}$and $\mathrm{CD}^{+} \mathrm{T}$ cells from patients with active MCTD produced significantly more IL-10 than cells in patients with inactive disease or in healthy individuals [68]. MCTD is characterized by various $\mathrm{T}$ cell abnormalities, which becomes explicit in the active phase of the disease. Formerly, it was demonstrated that the ratios of peripheral natural Treg cells in patients with MCTD were decreased, especially in patients with active disease. On the other hand, an increase in inducible, IL-10-secreting CD4+IL-10+ Tr1 cells was reported in the disease. The Tr1 cells ratio further increased in patients with active disease. Tr1 cell percentages could represent a compensatory mechanism between type 1 and type 2 cytokine-level harmonization in MCTD [22]. Serum levels of IFN- $\gamma$ and TNF- $\alpha$ were increased along with reduced number of Tregs. The decreased levels of regulatory $\mathrm{T}$ cells, along with the increased expression of proinflammatory cytokines may tip the fine balance towards autoimmunity in a subset of MCTD patients [69]. Serum and intracellular cytokine assessment, cellular immune-regulatory functional tests are valuable to estimate disease activity in MCTD, as well as may help in subcategorizing these patients [70]. 
Taken these findings together, in all these various patient groups with autoimmune conditions, we could identify a circulating cytokine imbalance, a pro-inflammatory milieu, and the development of Th17 cells along with the reduction in numbers/function of various regulatory cell types. The simultaneous, opposing effect of Th17 cells and Tregs has a strong impact on immune homeostasis, deciding and controlling the development of autoimmunity in these patients.

\section{Regulatory cells in transplant immunology}

One of the major goals in organ transplantation is to achieve indefinite allograft survival without the need for life-long immunosuppression. Over last 10-12 years, it has become clear that the balance between of alloantigen-reactive effector cells and the regulatory immune cells will ultimately determine whether a graft is accepted or rejected [71]. The potential use of different regulatory cells as cellular therapies to support long-term graft function is also emerging. Thus, understanding the characteristics of these regulatory populations is paramount.

Following transplantation, both innate and adoptive arms of the immune response are triggered. Surgical stress and ischemia/reperfusion injury (IRI) create an inflammatory environment in the graft which affects cells of both donor and recipient origin. Recipient cells migrate into the graft, and are activated by the locally produced pro-inflammatory cytokines. Donor-derived, resident DCs and macrophages are also attracted to the site of inflammation which leads to the development regulatory properties in these cells. These cells migrate to the draining lymphoid tissue, where they initiate $\mathrm{T}$ cell activation [72]. Activated T cells return to the allograft, and donor alloantigens presented by donor-derived or recipient antigen presenting cells (APCs) could promote the expansion and generation of Treg and/or 
regulatory B cell populations. The number and power of regulatory immune cells, including those that pre-existed in the recipient or were generated during the course of the response, are not sufficient in the early stage of the allo-response to counteract the effect of various of leukocytes attacking the graft in the absence of immunosuppressive therapy.

Long-term allograft survival without continuous drug-based immunosuppression called operational transplantation tolerance has been evidenced by both experimental and clinical data $[73,74]$. Various leukocyte sets have been associated with regulatory functions including macrophages, MDSCs, DCs and mesenchymal stromal cells (MSCs), as well as different subsets of T and B cells. They origin, development, phenotype and function has been studied extensively.

\subsection{Regulatory macrophages}

Macrophages are essential component of innate immunity and migrate into inflamed tissues in response to injury. Depending on the microenvironment, macrophages can mount specific functional activities. Classical proinflammatory M1 macrophages are characterized by high levels of proinflammatory cytokines and by promotion of a Th1 response. In contrast, alternatively activated M2 macrophages are thought to be involved in the resolution of tissue inflammation apart from having immunoregulatory functions. Regulatory macrophages (Mreg) are an additional, uniquely characterized group of cells expressing a profile of distinct group of cellular markers, and are able to decrease pro-inflammatory immune responses [75]. Regulatory macrophages produce IL-10 but do not express arginase 1. Mouse Mreg have been shown to inhibit $\mathrm{T}$ cell activity in vitro via inducible nitric oxide synthase (iNOS) and delete co-cultured allogeneic T cells via phagocytosis [76]. Human Mreg are suppressive of T cell proliferation via IFN- $\gamma$ induced indoleamine 2,3-dioxygenase (IDO) activity and contactdependent deletion of activated T cells [77]. 


\subsection{Dendritic cells}

DCs are essential for priming antigen-specific $\mathrm{T}$ cell responses to alloantigens, but they may also promote tolerogenic responses. It appears that both myeloid (mDCs) and plasmocytoid DCs are able to promote tolerance to alloantigens but DCs' main function is to prime the immune system. Injection of immature DCs harvested from the donor-extends the survival of various allografts when given prior to transplantation [78-80]. In a different model, pDCs were shown to acquire alloantigens while in the allograft, and induced the generation of Treg cells after migrating to the draining lymphoid tissue [81].

pDCs may contribute to immune regulation in liver transplant recipients suggested by higher ratios of pDCs to mDCs found in those with no or decreased immunosuppression. Phenotypic changes, including increased expression of PD-1 ligand and CD86, on pDCs correlated with elevated numbers of $\mathrm{CD} 4{ }^{+} \mathrm{CD} 25^{\mathrm{hi}} \mathrm{FOXP}^{+}$Treg cells in liver transplant free from immunosuppressive treatment $[82,83]$.

\subsection{Myeloid-derived suppressor cells}

Myeloid-derived suppressor cells are a heterogeneous population of bone marrow-derived myeloid progenitors. In different pathological conditions such as malignant tumors, infections, transplanted organs and autoimmune diseases, MDSC populations expand and can be detected in the blood, peripheral lymphoid tissues, the spleen, cancerous tissues and inflammatory sites including different grafted organs.

In transplantation, MDSCs have been shown to promote tolerance to alloantigens, as there is direct evidence of a tolerogenic role for MDSCs in heart and islet allografts in mice [84,85], and for inducible nitric oxide synthase (iNOS)-expressing MDSCs in a rat kidney allograft model. Injection of Lacto-N-fucopentaose III activated m-MDSCs results in prolonged graft 
survival [86]. The mechanisms used by MDSCs to promote tolerance to alloantigens require further clarification. Some evidence suggests that they may act partly through the induction or sparing of Treg cells. Recent studies in human kidney transplant recipients demonstrated that

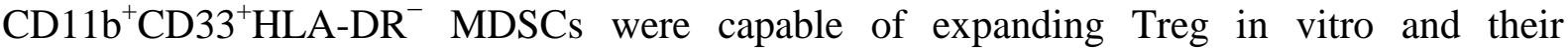
accumulation after transplantation correlated with an increase in Treg in vivo [87]. MDSCsdependent expansion of Treg was suggested to be mediated by the production of soluble factors such as TGF- $\beta$ and IL-10.

\subsection{Mesenchymal stromal cells}

Bone marrow-derived MSCs have the ability to move to sites of inflammation, and can also migrate to transplanted organ. The effects of MSCs on the adaptive immune response are closely connected to the effects on the innate arm as myeloid cells are probably the first cells to be affected. MSCs exert their effects on a large spectrum of, including T cells, B cells, natural killer cells, monocytes/macrophages, dendritic cells and neutrophils $[88,89]$. They hinder the differentiation of dendritic cells, and inhibit their maturation into fully functional antigen-presenting cells [90]. They arrest activated T cells in the G0/G1 phase and decrease their production of IFN- $\gamma$ and IL-2. MSDs downregulate cytotoxic T lymphocyte-mediated cytotoxicity, and can press $\mathrm{CD}^{+} \mathrm{T}$ cells into regulatory phenotype and function. Additionally, MSCs alter the proliferation, cytotoxicity, and IFN- $\gamma$ production of natural killer cells, and $\gamma \delta$ T cells $[91,92]$.

When MSCs are exposed to the graft's inflammatory microenvironment, they display unique immunomodulatory features. On one hand, MSCs inhibit effector T-cell responses but promote the emergence and expansion of regulatory T cells. MSC infusion in experimental models of solid organ transplantation results in Treg-mediated tolerance. MSC synergistic effect with low-dose or transient pharmacological immunosuppression in inducing long-term 
graft survival has also been observed. MSCs have been shown to promote the generation of Treg cells both in vitro and in vivo through mechanisms involving prostaglandin E2, TGF $\beta$ and cell-cell contact $[93,84]$. In addition, MSCs may promote the acceptance of allogeneic islets by secreting matrix metalloproteinases, and suppression of graft rejection by inhibiting alloantibody production has also been reported $[85,94]$.

\section{5. $C D 4^{+}$regulatory $T$ cells}

The naturally arising, thymus-derived Treg cells primarily suppress responses to selfantigens, but are also able to react to donor alloantigens via cross-reactivity. These cells initially inhibit $\mathrm{T}$ cell activation and the development of the effector-type adaptive immune response in the draining lymphoid tissue [95]. Induced Treg cells are generated in response to donor-derived alloantigen. As the allograft provides Treg cells with continuous exposure to graft-derived antigens, induced Treg cells may be more important promoting graft acceptance [96,97].

\section{6. $C D 8^{+}$regulatory $T$ cells}

$\mathrm{CD}^{+}$regulatory $\mathrm{T}$ cells have various phenotypes, including $\mathrm{CD}^{+} \mathrm{CD} 28^{-}, \mathrm{CD}^{+} \mathrm{CD} 103^{+}$, $\mathrm{CD}^{+} \mathrm{FoxP}^{+}$and $\mathrm{CD} 8^{+} \mathrm{CD} 122^{+}$subsets. Through the secretion several immunosuppressive cytokines including IL-4, IL-10 and TGF- $\beta$, and by direct killing of target cells via Fas L/Fas and the perforin/granzyme B pathways, they exhibit suppressive function in both allo- and autoimmune animal models. $\mathrm{CD} 8^{+} \mathrm{CD} 28^{-} \mathrm{FoxP}^{+}$Treg suppress alloimmune responses by inducing immunoglobulin-like transcript (ILT) $3^{+} / \mathrm{ILT}^{+}$tolerogenic endothelial cells, and by down-regulating the expression of costimulatory and adhesion molecules [98-101]. Transfer of $\mathrm{CD}^{+} \mathrm{CD} 28^{-}$Treg from tolerized liver transplant recipients improved acute allograft rejection in rats [102]. 
The presence of circulating $\mathrm{CD} 8^{+} \mathrm{CD} 28^{-}$Treg was associated with good graft in patients receiving liver-intestine grafts even with reduced or absent immunosuppression [103]. In adult liver transplant patients, expansion of $\mathrm{CD} 8^{+} \mathrm{CD} 28^{-}$Treg population correlated with lower occurrence of acute or chronic rejection [104]. $\mathrm{CD}^{+} \mathrm{CD} 28^{-}$cells have been identified in renal transplant recipients treated with the anti-CD52 monoclonal antibody alemtuzumab [105]. These observations demonstrate that $\mathrm{CD} 8^{+} \mathrm{CD} 28^{-}$cells are primary effectors of transplant tolerance, and they target the endothelium and APC to induce a tolerogenic phenotype and inhibit $\mathrm{CD} 4^{+} \mathrm{T}$ helper cell alloreactivity.

New observations imply that another $\mathrm{CD} 8^{+}$subset, the $\mathrm{CD} 8^{+} \mathrm{CD} 122^{+}$Treg, may also have a role in suppressing alloimmunity. $\mathrm{CD}^{+} \mathrm{CD} 122^{+}$cells suppressed murine allograft rejection even more effectively than their $\mathrm{CD} 4^{+} \mathrm{CD} 25^{+}$counterparts $[106,107]$.

\section{7. $\gamma \delta$ T cells}

The $\gamma \delta \mathrm{T}$ cells are innate-type $\mathrm{T}$ cells which may also have a regulatory role in transplant patients as an altered distribution of $\mathrm{V} \delta 1$ - and $\mathrm{V} \delta 2$-expressing $\gamma \delta \mathrm{T}$ cell subsets has been reported in operationally tolerant liver transplant recipients compared with non-transplant control $[108,109]$. Additional extended studies in large populations of allograft recipients suggest that alterations in the $\gamma \delta \mathrm{T}$ cell compartment are not limited to tolerant liver recipients. An increased $\gamma \delta$ T cell pool was detected in the peripheral blood of most immunosuppressed liver and kidney recipients. The increase was mainly a result of the expansion of V $\delta 1 \mathrm{~T}$ cells. The specific functional role of $\gamma \delta \mathrm{T}$ has yet to be described, as persistent viral infections are also likely to contribute to these alterations [110].

\section{8. $T_{F H}$ cells}


In the last ten years, several article indicated the activated B cell involvement in allograft rejection, therefore antibody-mediated rejection (AMR) has increasingly been recognized as a cause of graft damage, dysfunction and loss. The definition of AMR continues to evolve with the latest Banff classification adding criteria to include AMR without immunohistochemical evidence of C4d deposition [111]. The requirements include evidence of tissue injury, antibody interaction with vascular endothelium and the presence of donor-specific antibody. The significance of $\mathrm{T}_{\mathrm{FH}}$ cells in transplantation has not been fully elucidated yet. B-cell production of high-affinity alloantibody requires $\mathrm{T}$ cell help via the indirect pathway of allorecognition. T-cell help must be provided by the interaction between T-cell receptors and class II MHC-peptide complexes on recipient B cells (indirect allorecognition), as opposed to the direct pathway involving direct recognition of donor MHC on donor-derived antigen presenting cells by recipient $\mathrm{T}$ cells [112]. Number of studies on circulating $\mathrm{T}_{\mathrm{FH}}$ in human transplantation is limited. Graav et al [113] demonstrated that circulating $\mathrm{T}_{\mathrm{FH}}$ cells in human transplantation are reduced immediately post transplant and at 3 months. Patients with preexisting donor-specific antibodies had higher numbers of circulating $\mathrm{T}_{\mathrm{FH}}$ cells at 3 months compared with those without. These circulating $\mathrm{T}_{\mathrm{FH}}$ cells in transplant patients was able to induce B cell proliferation and immunoglobulin production in an IL-21-dependent manner. Although $\mathrm{T}_{\mathrm{FH}}$ cells presumably play a central role in the generation of high affinity alloantibody, and the consequential develpoment of AMR, the relative contributions of the various populations of $\mathrm{T}_{\mathrm{FH}}$ cells in lymph nodes, circulation and allograft require further investigation.

\subsection{Regulatory B cells}

The role of B cells in transplantation is beginning to emerge in both animal models and humans. Allogenic donor B cells administrated in combination with anti-CD40L permit the 
survival of islet as well as murine cardiac allografts $[114,115]$. Targeting CD45 via antiCD45-RB after transplantation prevents cardiac allograft rejection. This requires host B cells and interaction of co-stimulatory molecules on B cells and $\mathrm{T}$ cells as tolerance could not be induced in transgenic mice lacking B cells and antibodies but and can be achieved with B-cell transfer [116-118]. Neutralization of IL-10 enhances tolerance induction and improves the long-term outcomes of cardiac allograft, and Il-10 expression by B-lymphocytes inhibits Bcell-mediated tolerance induction. Murine studies established a role for $\mathrm{T}$ cell immunoglobulin and mucin domain-containing protein 1 (TIMD1) on B cells as its ligation promotes population B cells expansion and regulatory activity [119]. Combined effects of anti-CD45-RB and anti-TIM-1 antibodies have also been investigated in a mouse islet allograft model. This model is dependent on the production of IL-10 by B cells since transfer of IL-10 deficient B cells does not prolong allograft survival. The importance of interactions between TIM-1+ regulatory B-cell/Treg was demonstrated by the observation that depletion of Treg prior transplantation results in rejection [120]. Other studies have shown that IgM+ B cells, but not IgG+ B cells, form clusters within kidney allografts in tolerant rats, and this finding has been interpreted as indicating the presence of B cells with regulatory activity [121].

In humans, most results are from patients with operational tolerance. A specific B cell gene signature in blood of patients that spontaneously developed operational tolerance to kidney transplant after immuno-suppressive treatment withdrawal has been identified by several groups: higher mRNA expression of immunoglobulin light chains, CD20 as well as proliferation and cell cycle genes $[122,123]$. The mechanism of this suppression mediated by B cells is not fully understood but TGF could play a function as some of modulated genes are target of TGF [124]. Consistent with a regulatory function for B cells in human transplantation, a clinical trial has shown increased risk for acute cellular rejection following 
depletion of B cells prior to transplantation. This could be due to a loss of regulatory B cells [125].

\section{New therapeutic approaches to modulation regulatory cells in autoimmune diseases} and transplantation

Cell-based therapies have been studied extensively for their capacity to induce tolerance. Mesenchymal stem cells, regulatory myeloid cells, T regulatory cells, and other cell types are being tested for tolerance induction. Early results with these cell types have been promising, regimens resulting in consistent tolerance, however, have yet to be established.

Regarding Treg cell-based therapies, one of the major challenges in developing is to consistently obtain sufficient numbers of cells for adoptive transfer, since only approximately $1 \%$ of peripheral blood mononuclear cells are Treg cells. Various kinds of Treg cell expansion methods have been explored. It was recently revealed that 3500 -fold is achievable after 14 days culture in the presence of high amounts of IL-2, T cell expander beads at a ratio of four beads per cell and $100 \mathrm{~nm}$ rapamycin. These expanded human Treg cells expressed higher level of Foxp3 than fresh Treg, and had enhanced regulatory ability [126]. However, one of the major hurdles to be overcome is to expand antigen-specific Treg cells, in order to avoid a generalised immunosuppression. The current technology does not easily permit the identification of disease-associated self-antigen specific Treg cells [127]. Additionally, the studies on the effectiveness of $\mathrm{CD} 4^{+} \mathrm{CD} 25^{+}$Treg transplant in the treatment of autoimmune diseases have been mainly evaluated in animal trials only. Nevertheless, the in vitro expansion of Treg cells from autoimmune patients reversed the Treg cell functional defect 
[127]. Thus, Treg cell therapy might be a rational approach for the treatment, and investigators are currently attempting to expand its use in autoimmune diseases [128].

Regrading solid organ transplantation, Tregs have been shown to have therapeutic effects, albeit, may not have sufficient potency as a stand-alone therapy [129-132]. They can be expanded ex vivo and administered exogenously, or transplanted as part of a tolerated graft. There are several clinical trials utilizing the infusion of ex vivo generated Treg, including renal and liver transplant patients. Factors critical to the efficacy of Treg therapy in transplantation are dose, specificity, and adjunct immunosuppression. The future of Treg therapy depends on effective clinical trial designs, advancement in Treg manufacture, and further understanding of Treg biology as well as transplantation tolerance in clinical setting.

Current experimental data place $\mathrm{T}_{\mathrm{FH}}$ cells in a central role in the formation of high affinity alloantibody resulting in the development of AMR. Further study should clarify attributes of the $\mathrm{T}_{\mathrm{FH}}$ cell subsets and also identify increasingly precise targets for therapy that may interrupt their function.

Therapeutic approaches targeting DCs for treatment of autoimmune diseases are aimed at either diminishing their immunogenic potential or enhancing their tolerogeneic features. DCs with tolerogenic properties (tolDCs) and loaded with autoantigens may potentially restore self-tolerance by modulating not only Treg subsets but by inducing antigen-specific anergy and hyporesponsiveness of $\mathrm{T}$ cells and promoting the generation of Breg cell, as well. $[133,134]$. In humans, plasmacytoid DCs seem to play a role in the differentation of immature B cells into Bregs [135]. Furthermore, it was reported that tolDCs induce a significant increase in Breg number by the expansion of the already existing Breg population and the conversion of $\mathrm{CD} 19^{+} \mathrm{B}$ cells into IL-10-producing Bregs [136]. Numerous procedures have been described to obtain tolDCs from monocytes ex vivo, and accumulating evidence from the experimental use of tolDCs in autoimmune diseases such as rheumatoid arthritis (RA), 
type 1 diabetes (T1D), atherosclerosis and multiple sclerosis supports the therapeutic potential of tolerogeneic DCs. However, the use of ex vivo-generated tolerogeneic DCs in the treatment of SLE has not yet been reported $[10,137]$. Currently, there are only a limited number of clinical trials using tolDCs in autoimmune diseases. Intradermally administration of autologous monocyte-derived tolDCs led to increased Breg cell proportions in T1D patients and increased Treg/T effector ratios in RA patients, without any side effects $[138,139]$.

Treatment with MSCs has been tested in many autoimmune diseases, including refractory SLE, systemic sclerosis, Crohn's disease, type I diabetes and collagen-induced arthritis [140]. Recently, Sun et al. reported over 30 patients with refractory SLE who received cultureexpanded MScs grafts. These patients demonstrated a rapid amelioration of fatigue, proteinuria, ascites and arthralgias. Clinical data showed that the Disease Activity Index (SLEDAI) was significantly improved after treatment with umbilical cord (UC)-derived mesenchymal stem cells (MSCs) [141].

MSCs_are a promising candidate for cell-based therapies in kidney transplantation, as well. $[142,143]$. Their efficacy depends on the relative amounts of proinflammatory and antiinflammatory cytokines. Relevant biomarkers are needed to monitor the inflammatory status of patient to optimize treatment. This may include proportion of regulatory $\mathrm{T}$ cells, $\mathrm{T}$-cell polarization balance as well as plasma levels of inflammatory cytokines and chemokines. Quantification of indoleamine 2,3 dioxygenase activity in plasma can also be helpful.

MDSCs were shown, in a rat kidney transplant model, to induce tolerance via anti-CD28 and to accumulate within the allograft [144]. Prolonged survival of islet cell allograft, cotransplanted with MDSC, has also been demonstrated [145]. In humans, MDSCs have been found upregulated after transplantation [146]. Nonetheless, utilization of MDSC as cellular therapy in human transplantation remains hampered do to our still incomplete understanding 
of their phenotype, differentiation, functions, and interactions with the inflammatory microenvironment.

Regulatory macrophages (Mreg) offer are an appealing possibility for cellular therapy to obtain tolerance induction in human recipients. In an early trial, the cells were generated by culturing donor splenic mononuclear cells in macrophage colony-stimulating factor with stimulation with IFN- $\gamma$. No acute or late adverse reactions were reported when cells were infused (M-CSF) into kidney recipients receiving grafts from deceased donors [147]. Several trials have shown that living-related kidney transplant recipients can be treated preoperatively with Mreg, generated by culturing donor peripheral blood mononuclear cells (PBMCs) in MCSF with IFN- $\gamma$, followed by co-culturing with recipient PBMC. Outcomes were different, but some patients were stable for extended periods of time with minimal immunosuppression $[148,149]$. Ongoing trials are further evaluating the safety and efficacy of cellular therapies, including Mreg, in achieving tolerance in transplant recipients [150].

\section{Conclusions}

The immune system is normally well balanced to cope with invading pathogens and to tolerate non-dangerous stimuli. The intricate interplay of various proinflammatory cytokines and chemokines, orchestrated by key regulators of the immune system, can lead to the imbalance between regulatory and proinflammatory cells. The breakdown in immune tolerance results in the activation of auto-reactive $\mathrm{T}$ and $\mathrm{B}$ cells, and with a susceptible genetic background, this can lead to the development of a fullblown autoimmune disease. The concept of utilizing cells that regulate the development of autoimmunity has led to the identification of cell-based therapies for the treatment of autoimmune diseases. Investigations 
on transplant immunlogy revealed that these approaches to modulate tolerogenic immune cells could be also beneficial to avoid transplant rejection. Since data are still limited, more trials are needed to establish the proper drug dosages, the number of administered cells and the treatment intervals. We believe that this approach will aid in the diagnosis and therapy design in autoimmune diseases and organ transplantation and will provide an advanced disease management in the near future.

\section{Take-home messages}

- Better understanding of the alterations in immunological tolerance is crucial for the effective therapy of autoimmune diseases.

- Despite the potent immunosuppressive medications, induction of tolerance remains a major goal in solid organ transplantation as well.

- Novel results on the modification of immune-regulatory processes and tolerogenic mechanisms may open new avenues in the treatment of autoimmune diseases as well as transplant rejection.

\section{Conflict of Interest}

This research did not receive any specific grant from funding agencies in the public, commercial, or not-for-profit sectors. The authors declare that there is no conflict of interests regarding the publication of this paper. 


\section{References}

[1] Davies AJ. Immunological tolerance and the autoimmune response. Autoimmun Rev $2008 ; 7: 538-43$

[2] Nagy G, Huszthy PC, Fossum E, Konttinen Y, Nakken B, Szodoray P. Selected Aspects in the Pathogenesis of Autoimmune Diseases. Mediators Inflamm $2015 ; 2015: 351732$

[3] Alegre ML, Lakkis FG, Morelli AE. Antigen Presentation in Transplantation. Trends Immunol 2016;37:831-43.

[4] Takeuchi O, Akira S. Pattern recognition receptors and inflammation. Cell 2010;140:805-20.

[5] Liu J, Cao X. Cellular and molecular regulation of innate inflammatory responses. Cell Mol Immunol 2016;13:711-21.

[6] Jaehn PS, Zaenker KS, Schmitz J, Dzionek A. Functional dichotomy of plasmacytoid dendritic cells: antigen-specific activation of $\mathrm{T}$ cells versus production of type $\mathrm{I}$ interferon. Eur J Immunol 2008;38:1822-32.

[7] Jongbloed SL, Kassianos AJ, McDonald KJ, Clark GJ, Ju X, Angel CE, et al. Human CD141+ (BDCA-3)+ dendritic cells (DCs) represent a unique myeloid DC subset that cross-presents necrotic cell antigens. J Exp Med 2010;207:1247-60.

[8] Mueller SN. Skin DCs cluster for efficient $\mathrm{T}$ cell activation. Nat Immunol 2014;15:1004-5;

[9] Woodruff MC, Turley SJ. Chemokine 'grooming' by cLECs directs DC migration. Nat Immunol 2014;15:595-6. 
[10] García-González P, Ubilla-Olguín G, Catalán D, Schinnerling K, Aguillón JC. Tolerogenic dendritic cells for reprogramming of lymphocyte responses in autoimmune diseases. Autoimmun Rev 2016;15:1071-80.

[11] Sela U, Olds P, Park A, Schlesinger SJ, Steinman RM. Dendritic cells induce antigenspecific regulatory $\mathrm{T}$ cells that prevent graft versus host disease and persist in mice. $\mathrm{J}$ Exp Med 2011;208:2489-96.

[12] Boros P, Ochando J, Zeher M. Myeloid derived suppressor cells and autoimmunity. Hum Immunol 2016;77:631-6.

[13] Toda A, Piccirillo CA. Development and function of naturally occurring CD4+CD25+ regulatory T cells. J Leukoc Biol 2006;80:458-70.

[14] Dwivedi M, Kemp EH, Laddha NC, Mansuri MS, Weetman AP, Begum R. Regulatory $\mathrm{T}$ cells in vitiligo: Implications for pathogenesis and therapeutics. Autoimmun Rev 2015;14:49-56.

[15] Roncarolo MG, Bacchetta R, Bordignon C, Narula S, Levings MK. Type 1 T regulatory cells. Immunol Rev 2001;182:68-79.

[16] Weiner HL. Induction and mechanism of action of transforming growth factor-betasecreting Th3 regulatory cells. Immunol Rev 2001;182:207-14.

[17] Dwivedi M, Kumar P, Laddha NC, Kemp EH. Induction of regulatory T cells: A role for probiotics and prebiotics to suppress autoimmunity. Autoimmun Rev 2016;15:37992.

[18] Papp G, Szabó K, Szekanecz Z, Zeher M. Follicular helper T cells in autoimmune diseases. Rheumatology (Oxford) 2014;53:1159-60.

[19] Dhaeze T, Stinissen P, Liston A, Hellings N. Humoral autoimmunity: a failure of regulatory T cells? Autoimmun Rev 2015;14:735-41. 
[20] Yang M, Rui K, Wang S, Lu L. Regulatory B cells in autoimmune diseases. Cell Mol Immunol 2013;10:122-32.

[21] Ding T, Yan F, Cao S, Ren X. Regulatory B cell: New member of immunosuppressive cell club. Hum Immunol 2015;76:615-21.

[22] Baráth S, Sipka S, Aleksza M, Szegedi A, Szodoray P, Végh J, Szegedi G, Bodolay E. Regulatory T-cells in peripheral blood of patients with mixed connective tissue disease. Scand J Rheumatol 2006;35:300-4.

[23] Dejaco C, Duftner C, Grubeck-Loebenstein B, Schirmer M. Imbalance of regulatory T cells in human autoimmune diseases. Immunology 2006;117:289-300.

[24] Liu MF, Wang CR, Fung LL, Wu CR. Decreased CD4+CD25+ T-cells in peripheral blood of patients with systemic lupus erythematosus. Scand J Immunol 2004;59:198202.

[25] Szodoray P, Papp G, Horvath IF, Barath S, Sipka S, Nakken B, Zeher M. Cells with regulatory function of the innate and adaptive immune system in primary Sjögren's syndrome. Clin Exp Immunol 2009;157:343-9.

[26] Valencia X, Yarboro C, Illei G, Lipsky PE. Deficient CD4+CD25high T regulatory cell function in patients with active systemic lupus erythematosus. J Immunol 2007; 178:2579-88.

[27] Grant CR, Liberal R, Mieli-Vergani G, Vergani D, Longhi MS. Regulatory T-cells in autoimmune diseases: challenges, controversies and-yet-unanswered questions. Autoimmun Rev 2015;14:105-16.

[28] Szodoray P, Nakken B, Barath S, Gaal J, Aleksza M, Zeher M, et al. Progressive divergent shifts in natural and induced T-regulatory cells signify the transition from undifferentiated to definitive connective tissue disease. Int Immunol 2008;20:971-9. 
[29] Lee JH, Wang LC, Lin YT, Yang YH, Lin DT, Chiang BL. Inverse correlation between CD4 regulatory $\mathrm{T}$-cell population and autoantibody levels in paediatric patients with systemic lupus erythematosus. Immunology 2006;117:280-6.

[30] Roncarolo MG, Gregori S, Battaglia M, Bacchetta R, Fleischhauer K. Levings M.K. Interleukin-10-secreting type 1 regulatory $\mathrm{T}$ cells in rodents and humans. Immunol Rev 2006;212:28-50.

[31] Constant SL, Bottomly K. Induction of Th1 and Th2 CD4+ T-cell responses: the alternative approaches. Annu Rev Immunol. 1997;15:297-322.

[32] Moore KW, de Waal Malefyt R, Coffman RL, O'Garra A. Interleukin 10 and the interleukin-10 receptor. Annu Rev Immunol 2001;19:683-765.

[33] Kim BS, Park YJ, Chung Y. Targeting IL-17 in autoimmunity and inflammation. Arch Pharm Res 2016;39:1537-47.

[34] Steinman L. A rush to judgment on Th17. J Exp Med 2008;205:1517-22.

[35] Shin MS, Lee N, Kang I. Effector T-cell subsets in systemic lupus erythematosus: update focusing on Th17 cells. Curr Opin Rheumatol 2011;23:444-8.

[36] Lin X, Rui K, Deng J, Tian J, Wang X, Wang S, et al. Th17 cells play a critical role in the development of experimental Sjogren's syndrome. Ann Rheum Dis 2015;74:130210.

[37] Papp G, Horvath IF, Barath S, Gyimesi E, Sipka S, Szodoray P, Zeher M. Altered Tcell and regulatory cell repertoire in patients with diffuse cutaneous systemic sclerosis. Scand J Rheumatol 2011;40:205-10.

[38] Valencia $\mathrm{X}$, Lipsky PE. CD4+CD25+FoxP3+ regulatory $\mathrm{T}$ cells in autoimmune diseases. Nat Clin Pract Rheumatol 2007;3:619-26. 
[39] Zeher M. Sjögren's syndrome. In: Zeher M, Szodoray P, editors. Sjögren’s syndrome and associated disorders, 2006. Research Signpost. Kerala: Transworld Research Network; 2006, p. 1-7.

[40] Szodoray P, Nakken B. Selected molecular aspects behind the clinical picture of Sjögren's syndrome. In: Zeher M, Szodoray P, editors. Sjögren's syndrome and associated disorders, 2006. Research Signpost. Kerala: Transworld Research Network; 2006, p. 27-49.

[41] Ciccia F, Guggino G, Giardina A, Ferrante A, Carrubbi F, Giacomelli R, Triolo G. The role of innate and lymphoid IL-22-producing cells in the immunopathology of primary Sjögren's syndrome. Expert Rev Clin Immunol 2014;10:533-41.

[42] Szodoray P, Alex P, Jonsson MV, Knowlton N, Dozmorov I, Nakken B, et al. Distinct profiles of Sjögren's syndrome patients with ectopic salivary gland germinal centers revealed by serum cytokines and BAFF. Clin Immunol 2005;117:168-76.

[43] Illes A, Varoczy L, Papp G, Wilson PC, Alex P, Jonsson R, et al. Aspects of B-cell non-Hodgkin's lymphoma development: a transition from immune-reactivity to malignancy. Scand J Immunol 2009;69:387-400.

[44] Szodoray P, Alex P, Brun JG, Centola M, Jonsson R. Circulating cytokines in primary Sjögren's syndrome determined by a multiplex cytokine array system. Scand J Immunol 2004;59:592-9.

[45] Szabo K, Papp G, Dezso B, Zeher M. The histopathology of labial salivary glands in primary Sjögren's syndrome: focusing on follicular helper T cells in the inflammatory infiltrates. Mediators Inflamm 2014;2014:631787.

[46] Szabo K, Papp G, Barath S, Gyimesi E, Szanto A, Zeher M. Follicular helper T cells may play an important role in the severity of primary Sjögren's syndrome. Clin Immunol 2013;147:95-104. 
[47] Papp G, Gyimesi E, Szabó K, Zöld É, Zeher M. Increased IL-21 Expression Induces Granzyme B in Peripheral CD5(+) B Cells as a Potential Counter-Regulatory Effect in Primary Sjögren's Syndrome. Mediators Inflamm 2016;2016:4328372.

[48] Tsokos GC. Systemic lupus erythematosus. N Engl J Med 2011;365:2110-21.

[49] Aringer M, Smolen JS. Tumour necrosis factor and other proinflammatory cytokines in systemic lupus erythematosus: a rationale for therapeutic intervention. Lupus 2004; 13:344-7.

[50] Rönnblom L, Elkon KB. Cytokines as therapeutic targets in SLE. Nat Rev Rheumatol 2010;6:339-47.

[51] Niewold TB, Kelly JA, Flesch MH, Espinoza LR, Harley JB, Crow MK. Association of the IRF5 risk haplotype with high serum interferon-alpha activity in systemic lupus erythematosus patients. Arthritis Rheum 2008;58:2481-7.

[52] Kariuki SN, Kirou KA, MacDermott EJ, Barillas-Arias L, Crow MK, Niewold TB. Cutting edge: autoimmune disease risk variant of STAT4 confers increased sensitivity to IFN-alpha in lupus patients in vivo. J Immunol 2009;182:34-8.

[53] Vereecke L, Beyaert R, van Loo G. The ubiquitin-editing enzyme A20 (TNFAIP3) is a central regulator of immunopathology. Trends Immunol 2009;30:383-91.

[54] Munroe ME, Vista ES, Guthridge JM, Thompson LF, Merrill JT, James JA. Proinflammatory adaptive cytokine and shed tumor necrosis factor receptor levels are elevated preceding systemic lupus erythematosus disease flare. Arthritis Rheumatol 2014;66:1888-99.

[55] Barath S, Aleksza M, Tarr T, Sipka S, Szegedi G, Kiss E. Measurement of natural (CD4+CD25high) and inducible (CD4+IL-10+) regulatory $\mathrm{T}$ cells in patients with systemic lupus erythematosus. Lupus 2007;16:489-96. 
[56] Bonelli M, Savitskaya A, von Dalwigk K, Steiner CW, Aletaha D, Smolen JS, Scheinecker C. Quantitative and qualitative deficiencies of regulatory $\mathrm{T}$ cells in patients with systemic lupus erythematosus (SLE). Int Immunol 2008;20:861-8.

[57] Wong CK, Lit LC, Tam LS, Li EK, Wong PT, Lam CW. Hyperproduction of IL-23 and IL-17 in patients with systemic lupus erythematosus: implications for Th17mediated inflammation in auto-immunity. Clin Immunol 2008;127:385-93.

[58] Doreau A, Belot A, Bastid J, Riche B, Trescol-Biemont MC, Ranchin B, et al. Interleukin 17 acts in synergy with B cell-activating factor to influence B cell biology and the pathophysiology of systemic lupus erythematosus. Nat Immunol 2009;10:77885.

[59] Alunno A, Bartoloni E, Bistoni O, Nocentini G, Ronchetti S, Caterbi S, et al. Balance between regulatory $\mathrm{T}$ and Th17 cells in systemic lupus erythematosus: the old and the new. Clin Dev Immunol 2012;2012:823085.

[60] Szabó K, Papp G, Szántó A, Tarr T, Zeher M. A comprehensive investigation on the distribution of circulating follicular $\mathrm{T}$ helper cells and $\mathrm{B}$ cell subsets in primary Sjögren's syndrome and systemic lupus erythematosus. Clin Exp Immunol 2016;183:76-89.

[61] LeRoy EC, Medsger TA Jr. Criteria for the classification of early systemic sclerosis. J Rheumatol 2001;28:1573-6.

[62] Sakkas LI, Platsoucas CD. Is systemic sclerosis an antigen-driven T cell disease? Arthritis Rheum 2004;50:1721-33.

[63] Murata M, Fujimoto M, Matsushita T, Hamaguchi Y, Hasegawa M, Takehara K, et al. Clinical association of serum interleukin-17 levels in systemic sclerosis: is systemic sclerosis a Th17 disease? J Dermatol Sci 2008;50:240-2. 
[64] Deleuran B, Abraham DJ. Possible implication of the effector CD4+ T-cell subpopulation TH17 in the pathogenesis of systemic scleroderma. Nat Clin Pract Rheumatol 2007;3:682-3.

[65] Papp G, Barath S, Szegedi A, Szodoray P, Zeher M. The effects of extracorporeal photochemotherapy on $\mathrm{T}$ cell activation and regulatory mechanisms in patients with systemic sclerosis. Clin Rheumatol 2012;31:1293-9.

[66] Papp G, Horvath IF, Gyimesi E, Barath S, Vegh J, Szodoray P, Zeher M. The assessment of immune-regulatory effects of extracorporeal photopheresis in systemic sclerosis: a long-term follow-up study. Immunol Res 2016;64:404-11.

[67] Hoffman RW, Greidinger EL. Mixed connective tissue disease. Curr Opin Rheumatol 2000;12:386-90.

[68] Bodolay E, Aleksza M, Antal-Szalmás P, Végh J, Szodoray P, Soltész P, et al. Serum cytokine levels and type 1 and type 2 intracellular $\mathrm{T}$ cell cytokine profiles in mixed connective tissue disease. J Rheumatol 2002;29:2136-42.

[69] Hajas A, Szodoray P, Barath S, Sipka S, Rezes S, Zeher M, et al. Sensorineural hearing loss in patients with mixed connective tissue disease: immunological markers and cytokine levels. J Rheumatol 2009;36:1930-6.

[70] Hajas A, Sandor J, Csathy L, Csipo I, Barath S, Paragh G, et al. Vitamin D insufficiency in a large MCTD population. Autoimmun Rev 2011;10:317-24.

[71] Sagoo P, Perucha E, Sawitzki B, Tomiuk S, Stephens DA, Miqueu P, et al. Development of a cross-platform biomarker signature to detect renal transplant tolerance in humans. J Clin Invest 2010;120:1848-61.

[72] Larsen CP, Morris PJ, Austyn JM. Austyn. Migration of dendritic leukocytes form cardiac allografts into host spleens: a novel pathway for initiation of rejection. J Exp Med 1990;171:307-14. 
[73] Alexander SI, Smith N, Hu M, Verran D, Shun A, Dorney S, Smith A, Webster B, Shaw PJ, Lammi A, Stormon MO. Chimerism and tolerance in a recipient of a deceased-donor liver transplant. N Engl J Med 2008;358:369-74.

[74] Takatsuki M, Uemoto S, Inomata Y, Egawa H, Kiuchi T, Fujita S, et al. Weaning of immunosuppression in living donor liver transplant recipients. Transplantation 2001;72:449-54.

[75] Fleming BD, Mosser DM. Regulatory macrophages: setting the threshold for therapy. Eur J Immunol 2011;41:2498-502.

[76] Riquelme P, Tomiuk S, Kammler A, Fändrich F, Schlitt HJ, Geissler EK, Hutchinson JA. IFN- $\gamma$-induced iNOS expression in mouse regulatory macrophages prolongs allograft survival in fully immunocompetent recipients. Mol Ther 2013;21:409-22.

[77] Hutchinson JA, Riquelme P, Sawitzki B, Tomiuk S, Miqueu P, Zuhayra M, et al. Cutting edge: immunological consequences and trafficking of human regulatory macrophages administered to renal transplant recipients. J Immunol 2011;187:207278.

[78] Fu F, Li Y, Qian S, Lu L, Chambers F, Starzl TE, et al. Costimulatory moleculedeficient dendritic cell progenitors ( $\mathrm{MHC}$ class $\mathrm{II}^{+}, \mathrm{CD} 80^{\mathrm{dim}}, \mathrm{CD} 86^{-}$) prolong cardiac allograft survival in nonimmunosupressed recipients. Transplantation 1996;62:659-65.

[79] Lutz MB, Suri RM, Niimi M, Ogilvie AL, Kukutsch NA, Rössner S, et al. Immature dendritic cells generated with low doses of GM-CSF in the absence of IL-4 are maturation resistant and prolong allograft survival in vivo. Eur J Immunol 2000;30: 1813-22.

[80] Roelen DL, Schuurhuis DH, van den Boogaardt DE, Koekkoek K, van Miert PP, van Schip JJ, et al. Prolongation of skin graft survival by modulation of the alloimmune response with alternatively activated dendritic cells. Transplantation 2003;76:1608-15. 
[81] Ochando JC, Homma C, Yang Y, Hidalgo A, Garin A, Tacke F, et al. Alloantigenpresenting plasmacytoid dendritic cells mediate tolerance to vascularized grafts. Nat Immunol 2006;7:652-62.

[82] Tokita D, Mazariegos GV, Zahorchak AF, Chien N, Abe M, Raimondi G, Thomson AW. High PD-L1/CD86 ratio on plasmacytoid dendritic cells correlates with elevated T-regulatory cells in liver transplant tolerance. Transplantation 2008;85:369-77.

[83] Matta BM, Castellaneta A, Thomson AW. Tolerogenic plasmacytoid DC. Eur J Immunol 2010;40:2667-76.

[84] Zhang B, Liu R, Shi D, Liu X, Chen Y, Dou X, et al. Mesenchymal stem cells induce mature dendritic cells into a novel Jagged-2-dependent regulatory dendritic cell population. Blood 2009;113:46-57.

[85] Ge W, Jiang J, Baroja ML, Arp J, Zassoko R, Liu W, et al. Infusion of mesenchymal stem cells and rapamycin synergize to attenuate alloimmune responses and promote cardiac allograft tolerance. Am J Transplant 2009;9:1760-72.

[86] Dutta P, Hullett DA, Roenneburg DA, Torrealba JR, Sollinger HW, Harn DA, Burlingham WJ. Lacto-N-fucopentaose III, a pentasaccharide, prolongs heart transplant survival. Transplantation 2010;90:1071-8.

[87] Srivastava MK, Zhu L, Harris-White M, Kar UK, Huang M, Johnson MF, et al. Myeloid suppressor cell depletion augments antitumor activity in lung cancer. PLoS One 2012;7:e40677.

[88] Luan Y, Mosheir E, Menon MC, Wilson D, Woytovich C, Ochando J, Murphy B. Monocytic myeloid-derived suppressor cells accumulate in renal transplant patients and mediate CD4(+) Foxp3(+) Treg expansion. Am J Transplant 2013;13:3123-31.

[89] Le Blanc K, Mougiakakos D. Multipotent mesenchymal stromal cells and the innate immune system. Nat Rev Immunol 2012;12:383-96. 
[90] Nauta AJ, Kruisselbrink AB, Lurvink E, Willemze R, Fibbe WE. Mesenchymal stem cells inhibit generation and function of both CD34+-derived and monocyte-derived dendritic cells. J Immunol 2006;177:2080-7.

[91] Spaggiari GM, Capobianco A, Abdelrazik H, Becchetti F, Mingari MC, Moretta L. Mesenchymal stem cells inhibit natural killer-cell proliferation, cytotoxicity, and cytokine production: role of indoleamine 2,3-dioxygenase and prostaglandin E2. Blood 2008;111:1327-33.

[92] Prigione I, Benvenuto F, Bocca P, Battistini L, Uccelli A, Pistoia V. Reciprocal interactions between human mesenchymal stem cells and gammadelta $\mathrm{T}$ cells or invariant natural killer T cells. Stem Cells 2009;27:693-702.

[93] Casiraghi F, Azzollini N, Cassis P, Imberti B, Morigi M, Cugini D, et al. Pretransplant infusion of mesenchymal stem cells prolongs the survival of a semiallogeneic heart transplant through the generation of regulatory T cells. J Immunol 2008;181:3933-46.

[94] Ding Y, Xu D, Feng G, Bushell A, Muschel RJ, Wood KJ. Mesenchymal stem cells prevent the rejection of fully allogenic islet grafts by the immunosuppressive activity of matrix metalloproteinase-2 and -9. Diabetes 2009;58:1797-806.

[95] Carvalho-Gaspar M, Jones ND, Luo S, Martin L, Brook MO, Wood KJ. Location and time-dependent control of rejection by regulatory $\mathrm{T}$ cells culminates in a failure to generate memory T cells. J Immunol 2008;180:6640-8.

[96] Graca L, Cobbold SP, Waldmann H. Identification of regulatory T cells in tolerated allografts. J Exp Med 2002;195:1641-6.

[97] Kendal AR, Chen Y, Regateiro FS, Ma J, Adams E, Cobbold SP, Hori S, Waldmann H. Sustained suppression by Foxp $3^{+}$regulatory $\mathrm{T}$ cells is vital for infectious transplantation tolerance. J Exp Med 2011;208:2043-53. 
[98] Ciubotariu R, Li J, Colovai AI, Platt JL, Cortesini R, Suciu Foca Cortesini N. Human xenospecific $\mathrm{T}$ suppressor cells inhibit $\mathrm{T}$ helper cell proliferation to porcine aortic endothelial cells, and NF-kappaB activity in porcine APC. Hum Immunol $2001 ; 62: 470-8$

[99] Manavalan JS, Kim-Schulze S, Scotto L, Naiyer AJ, Vlad G, Colombo PC, et al. Alloantigen specific $\mathrm{CD}^{+} \mathrm{CD}^{-} 8^{-} \mathrm{FOXP}^{+}{ }^{+} \mathrm{T}$ suppressor cells induce $\mathrm{ILT}^{+}{ }^{+} \mathrm{ILT}^{+}$ tolerogenic endothelial cells, inhibiting alloreactivity. Int Immunol 2004;16:1055-68.

[100] Ciubotariu R, Colovai AI, Pennesi G, Liu Z, Smith D, Berlocco P, et al. Specific suppression of human $\mathrm{CD} 4^{+}$Th cell responses to pig $\mathrm{MHC}$ antigens by $\mathrm{CD} 8^{+} \mathrm{CD} 28^{-}$ regulatory T cells. J Immunol 1998;161:5193-202.

[101] Choi J, Enis DR, Koh KP, Shiao SL, Pober JS. T lymphocyte-endothelial cell interactions. Annu Rev Immunol 2004;22:683-709.

[102] Liu Y, Chen N, Chen G, You P. The protective effect of $\mathrm{CD} 8^{+} \mathrm{CD} 28^{-} \mathrm{T}$ suppressor cells on the acute rejection responses in rat liver transplantation. Transplant Proc 2007;39:3396-403.

[103] Sindhi R, Manavalan JS, Magill A, Suciu-Foca N, Zeevi A. Reduced immunosuppression in pediatric liver-intestine transplant recipients with $\mathrm{CD} 8^{+} \mathrm{CD} 28^{-}$ T-suppressor cells. Hum Immunol 2005;66:252-7.

[104] Lin YX, Yan LN, Li B, Wang LL, Wen TF, Zeng Y, et al. A significant expansion of $\mathrm{CD}^{+} \mathrm{CD}^{-} 8^{-}$T-suppressor cells in adult-to-adult living donor liver transplant recipients. Transplant Proc 2009;41:4229-31.

[105] Trzonkowski P, Zilvetti M, Chapman S, Wieckiewicz J, Sutherland A, Friend P, Wood KJ. Homeostatic repopulation by $\mathrm{CD}_{2} 8^{-} \mathrm{CD}^{+} \mathrm{T}$ cells in alemtuzumab-depleted kidney transplant recipients treated with reduced immunosuppression. Am J Transplant $2008 ; 8: 338-47$. 
[106] Dai H, Wan N, Zhang S, Moore Y, Wan F, Dai Z. Cutting edge: Programmed death-1 defines $\mathrm{CD}^{+} \mathrm{CD} 122^{+} \mathrm{T}$ cells as regulatory versus memory $\mathrm{T}$ cells. $\mathrm{J}$ Immunol 2010;185:803-7.

[107] Dai Z, Zhang S, Xie Q, Wu S, Su J, Li S, et al. Natural CD8 $8^{+}$D $122^{+}$T cells are more potent in suppression of allograft rejection than $\mathrm{CD} 4{ }^{+} \mathrm{CD} 25^{+}$regulatory $\mathrm{T}$ cells. Am $\mathrm{J}$ Transplant 2014;14:39-48.

[108] Li Y, Koshiba T, Yoshizawa A, Yonekawa Y, Masuda K, Ito A, et al. Analyses of peripheral blood mononuclear cells in operational tolerance after pediatric living donor liver transplantation. Am J Transplant 2004;4:2118-25.

[109] Mauri C, Gray D, Mushtaq N, Londei M. Prevention of arthritis by interleukin 10producing B cells. J Exp Med 2003;197:489-501.

[110] Puig-Pey I, Bohne F, Benítez C, López M, Martínez-Llordella M, Oppenheimer F, et al. Characterization of $\gamma \delta \mathrm{T}$ cell subsets in organ transplantation. Transpl Int 2010;23:1045-55.

[111] Haas M, Sis B, Racusen LC, Solez K, Glotz D, Colvin RB, et al; Banff meeting report writing committee. Banff 2013 Meeting Report: inclusion of C4d-negative antibodymediated rejection and antibodyassociated arterial lesions. Am J Transplant $2014 ; 14: 272-83$

[112] Walters GD, Vinuesa CG. T Follicular Helper Cells in Transplantation. Transplantation 2016;100:1650-5.

[113] de Graav GN, Dieterich M, Hesselink DA, Boer K, Clahsen-van Groningen MC, Kraaijeveld $\mathrm{R}$, et al. Follicular $\mathrm{T}$ helper cells and humoral reactivity in kidney transplant patients: Tfh cells in kidney transplantation. Clin Exp Immunol 2015;180:329-40. 
[114] Parker DC, Greiner DL, Phillips NE, Appel MC, Steele AW, Durie FH, et al. Survival of mouse pancreatic islet allografts in recipients treated with allogeneic small lymphocytes and antibody to CD40 ligand. Proc Natl Acad Sci U S A 1995;92:9560-4.

[115] Niimi M, Pearson TC, Larsen CP, Alexander DZ, Hollenbaugh D, Aruffo A, et al. The role of the CD40 pathway in alloantigen-induced hyporesponsiveness in vivo. J Immunol 1998;161:5331-7.

[116] Deng S, Moore DJ, Huang X, Lian MM, Mohiuddin M, Velededeoglu E, et al. Cutting edge: transplant tolerance induced by anti-CD45RB requires B lymphocytes. J Immunol 2007;178:6028-32.

[117] Huang X, Moore DJ, Mohiuddin M, Lian MM, Kim JI, Sonawane S, et al. Inhibition of ICAM-1/LFA-1 interactions prevents B-cell-dependent anti-CD45RB-induced transplantation tolerance. Transplantation 2008;85:675-80.

[118] Zhao G, Moore DJ, Lee KM, Kim JI, Duff PE, O'Connor MR, et al. An unexpected counter-regulatory role of IL-10 in B-lymphocyte-mediated transplantation tolerance. Am J Transplant 2010;10:796-801.

[119] Murray PJ, Wynn TA. Protective and pathogenic functions of macrophage subsets. Nat Rev Immunol 2011;11:723-37.

[120] Lee KM, Kim JI, Stott R, Soohoo J, O'Connor MR, Yeh H, et al. Anti-CD45RB/antiTIM-1-induced tolerance requires regulatory B cells. Am J Transplant 2012;12:20728.

[121] Le Texier L, Thebault P, Lavault A, Usal C, Merieau E, Quillard T, et al. Long-term allograft tolerance is characterized by the accumulation of $\mathrm{B}$ cells exhibiting an inhibited profile. Am J Transplant 2011;11:429-38. 
[122] Pallier A, Hillion S, Danger R, Giral M, Racapé M, Degauque N, et al. Patients with drug-free long-term graft function display increased numbers of peripheral B cells with a memory and inhibitory phenotype. Kidney Int 2010;78:503-13.

[123] Newell KA, Asare A, Kirk AD, Gisler TD, Bourcier K, Suthanthiran M, et al; Immune Tolerance Network ST507 Study Group. Identification of a B cell signature associated with renal transplant tolerance in humans. J Clin Invest 2010;120:1836-47.

[124] Brouard S, Mansfield E, Braud C, Li L, Giral M, Hsieh SC, et al. Identification of a peripheral blood transcriptional biomarker panel associated with operational renal allograft tolerance. Proc Natl Acad Sci U S A 2007;104:15448-53.

[125] Clatworthy MR, Watson CJ, Plotnek G, Bardsley V, Chaudhry AN, Bradley JA, Smith KG. B-cell-depleting induction therapy and acute cellular rejection. N Engl J Med 2009;360:2683-5.

[126] Wu J, Yi S, Ouyang L, Jimenez E, Simond D, Wang W, et al. In vitro expanded human $\mathrm{CD} 4+\mathrm{CD} 25+$ regulatory $\mathrm{T}$ cells are potent suppressors of $\mathrm{T}$-cell-mediated xenogeneic responses. Transplantation 2008;85:1841-8.

[127] Liao J, Chang C, Wu H, Lu Q. Cell-based_therapies_for_systemic lupus erythematosus. Autoimmun Rev 2015;14:43-8.

[128] Petrillo MG, Ronchetti S, Ricci E, Alunno A, Gerli R, Nocentini G, Riccardi C. GITR+ regulatory $\mathrm{T}$ cells in the treatment of autoimmune diseases. Autoimmun Rev 2015;14:117-26.

[129] Tang Q, Bluestone JA, Kang SM. CD4 ${ }^{+}$Foxp $^{+}$regulatory $\mathrm{T}$ cell therapy in transplantation. J Mol Cell Biol 2012;4:11-21.

[130] Hippen KL, Merkel SC, Schirm DK, Sieben CM, Sumstad D, Kadidlo DM, et al. Massive ex vivo expansion of human natural regulatory $\mathrm{T}$ cells $\left(\mathrm{T}_{\text {regs }}\right)$ with minimal loss of in vivo functional activity. Sci Transl Med 2011;3:83ra41. 
[131] Roncarolo MG, Battaglia M. Regulatory T-cell immunotherapy for tolerance to selfantigens and alloantigens in humans. Nat Rev Immunol 2007;7:585-8.

[132] Hester J, Schiopu A, Nadig SN, Wood KJ. Low-dose rapamycin treatment increases the ability of human regulatory $\mathrm{T}$ cells to inhibit transplant arteriosclerosis in vivo. Am J Transplant 2012;12:2008-16.

[133] Maggi J, Schafer C, Ubilla-Olguín G, Catalán D, Schinnerling K, Aguillón JC. Therapeutic Potential of Hyporesponsive CD4(+) T Cells in Autoimmunity. Front Immunol 2015;6:488.

[134] Volchenkov R, Karlsen M, Jonsson R, Appel S. Type 1 regulatory T cells and regulatory B cells induced by tolerogenic dendritic cells. Scand J Immunol 2013;77:246-54.

[135] Menon M, Blair PA, Isenberg DA, Mauri C. A Regulatory Feedback between Plasmacytoid Dendritic Cells and Regulatory B Cells Is Aberrant in Systemic Lupus Erythematosus. Immunity 2016;44:683-97.

[136] Di Caro V, Phillips B, Engman C, Harnaha J, Trucco M, Giannoukakis N. Retinoic acid-producing, ex-vivo-generated human tolerogenic dendritic cells induce the proliferation of immunosuppressive B lymphocytes. Clin Exp Immunol 2013;174:30217.

[137] Llanos C, Mackern-Oberti JP, Vega F, Jacobelli SH, Kalergis AM. Tolerogenic dendritic cells as a therapy for treating lupus. Clin Immunol 2013;148:237-45.

[138] Giannoukakis N, Phillips B, Finegold D, Harnaha J, Trucco M. Phase I (safety) study of autologous tolerogenic dendritic cells in type 1 diabetic patients. Diabetes Care 2011;34:2026-32. 
[139] Benham H, Nel HJ, Law SC, Mehdi AM, Street S, Ramnoruth N, et al. Citrullinated peptide dendritic cell immunotherapy in HLA risk genotype-positive rheumatoid arthritis patients. Sci Transl Med 2015;290:290ra87.

[140] Lisianyi MI. Mesenchymal stem cells and their immunological properties. Fiziol Zh 2013;59:126-34.

[141] Wang D, Li J, Zhang Y, Zhang M, Chen J, Li X, et al. Umbilical cordmesenchymal stem cell transplantation in active and refractory systemic lupus erythematosus: a multicenter clinical study. Arthritis Res Ther 2014;16:R79.

[142] Peng Y, Ke M, Xu L, Liu L, Chen X, Xia W, et al. Donor-derived mesenchymal stem cells combined with low-dose tacrolimus prevent acute rejection after renal transplantation: a clinical pilot study. Transplantation 2013;95:161-8.

[143] Tan J, Wu W, Xu X, Liao L, Zheng F, Messinger S, et al. Induction therapy with autologous mesenchymal stem cells in living-related kidney transplants: a randomized controlled trial. JAMA 2012;307:1169-77.

[144] Dilek N, Poirier N, Usal C, Martinet B, Blancho G, Vanhove B. Control of transplant tolerance and intragraft regulatory $\mathrm{T}$ cell localization by myeloid-derived suppressor cells and CCL5. J Immunol 2012;188:4209-16.

[145] Chou HS, Hsieh CC, Charles R, Wang L, Wagner T, Fung JJ, et al. Myeloid-derived suppressor cells protect islet transplants by B7-H1 mediated enhancement of $\mathrm{T}$ regulatory cells. Transplantation 2012;93:272-82.

[146] Dilek N, Vuillefroy de Silly R, Blancho G, Vanhove B. Myeloid-derived suppressor cells: mechanisms of action and recent advances in their role in transplant tolerance. Front Immunol 2012;3:208. 
[147] Hutchinson JA, Riquelme P, Brem-Exner BG, Schulze M, Matthäi M, Renders L, et al. Transplant acceptance-inducing cells as an immune-conditioning therapy in renal transplantation. Transpl Int 2008;21:728-41.

[148] Hutchinson JA, Brem-Exner BG, Riquelme P, Roelen D, Schulze M, Ivens K, et al. A cell-based approach to the minimization of immunosuppression in renal transplantation. Transpl Int 2008;21:742-54.

[149] Hutchinson JA, Roelen D, Riquelme P, Brem-Exner BG, Witzke O, Philipp T, et al. Preoperative treatment of a presensitized kidney transplant recipient with donorderived transplant acceptance-inducing cells. Transpl Int 2008;21:808-13.

[150] Geissler EK. The ONE Study compares cell therapy products in organ transplantation: introduction to a review series on suppressive monocyte-derived cells. Transplant Res 2012;1:11. 